\title{
A recent find of Ophrys insectifera (Orchidaceae) in Ukraine - will it survive another 100 years?
}

\author{
Jan ROLEČEK ${ }^{1,2 *}$ (1) \\ ${ }^{1}$ Institute of Botany of the Czech Academy of Sciences, Department of Paleoecology, 25/27 Lidická, Brno 60200, Czech Republic \\ ${ }^{2}$ Department of Botany and Zoology, Faculty of Science, Masaryk University, 2 Kotlářská, Brno 61137, Czech Republic
}

\begin{abstract}
Here I report the first find of Ophrys insectifera in Ukraine since 1920. A single individual was found at its last recorded site, Chortova Hora near Rohatyn (Ivano-Frankivsk Region). The species occurs in a steppe meadow habitat situated in the lower part of a steep northern slope. Local vegetation may be classified to a broadly circumscribed association Brachypodio pinnati-Molinietum arundinaceae from the alliance Cirsio-Brachypodion pinnati (class FestucoBrometea). I discuss possible causes of the long-term neglect of $O$. insectifera at the site, its habitat conditions and suitable conservation management. To ensure the continued occurrence of this poor competitor and other rare species, it is necessary to prevent accumulation of litter and successional changes of the grassland. Mowing, low-intensity grazing, controlled early spring burning or their combination may be suitable ways to achieve this.
\end{abstract}

Keywords: controlled burning, endangered species, habitat management, Opillia, plant distribution, succession, threats

Article history. Submitted 08 June 2021. Revised 20 August 2021. Published 30 August 2021

Citation. Roleček J. 2021. A recent find of Ophrys insectifera (Orchidaceae) in Ukraine - will it survive another 100 years? Ukrainian Botanical Journal, 78(4): 297-302. https://doi.org/10.15407/ukrbotj78.04.297

*Corresponding author (e-mail: honza.rolecek@,centrum.cz)

\section{Introduction}

Ophrys insectifera L. (Orchidaceae) is the most northerly distributed Ophrys species, with the range centred in France, Germany, and Switzerland, and extending to the British Isles, Baltic region, and Fennoscandia. In the south it reaches the Iberian, Apennine and Balkan peninsulas (Meusel et al., 1965-1992). In Eastern Europe it is rare, but reaches up to the South Urals (Galeyeva, 2006). Across its distribution range it favours calcareous habitats of various kinds, mainly nutrient poor semi-dry and mesic grasslands, thermophilous scrub, and open and semi-open woodlands, often dominated by pine. It may tolerate deeper shade in calcicolous beech woodlands (Stroh, 2015), and towards the western, northern, and eastern periphery of its distribution range it increasingly occupies calcareous wetlands (Wolff, 1951; Galeyeva,
2006; Roze et al., 2011; Stroh, 2015). While it is classified as Least Concern in the IUCN Red List (Rankou, 2011), it has retreated in many parts of its distribution range and is evaluated, e.g., as Critically Endangered in Bulgaria (Petrova, Vladimirov, 2009) and Denmark (Wind, 2019), Endangered in the Czech Republic (Grulich, Chobot, 2017) and Finland (Hyvärinen et al., 2019), Vulnerable in Poland (Kaźmierczakowa et al., 2016), Germany (Metzing et al., 2018), and Switzerland (Bornand et al., 2016), Declining in Russia (Bardunov, Novikov, 2008), and Rare in Romania (Oltean et al., 1994).

In Ukraine the species has always been very rare and a single documented record comes from Chortova Hora near Rohatyn, Ivano-Frankivsk Region (Kagalo, 2009). The species was found there in May 1920 by a Polish botanist S. Wierdak and the corresponding specimens are deposited in the Herbarium of the Ivan Franko

(C) 2021 J. Roleček. Published by the M.G. Kholodny Institute of Botany, NAS of Ukraine. This is an open access article under the terms of the Creative Commons Attribution License (http://creativecommons.org/licenses/by/4.0/), which permits use, distribution, and reproduction in any medium, provided the original work is properly cited 
National University of Lviv (Dmytrash-Vatseba, 2018; Shumska, Dmytrash-Vatseba, 2018) and the Herbarium of the W. Szafer Institute of Botany, Polish Academy of Sciences in Krakow (B. Paszko, in litt.). The occurrence was never confirmed and the species was considered probably extinct there (Dmytrash-Vatseba, 2018). Other records in Ukraine are even older and are based only on literature data. They all come from the western part of the country, including the Eastern Carpathians (Bukovynian Carpathians, Gorgany), Northern Podillia, Opillia, and Roztochia (Kagalo, 2009; Chorney et al., 2010). Thus, the species has not been recorded in the territory of Ukraine for a century and is included in the Red Data Book of Ukraine with the highest category of threat, as Disappearing (Kagalo, 2009).

Here we report a recent find of $O$. insectifera in Ukraine, describe its habitat conditions, discuss possible causes of its long-term neglect, and propose suitable conservation management.

\section{Study area}

Chortova Hora (333 m a.s.1.) is a famous hill and a natural site near the town of Rohatyn in the western part of Ukraine (Ivano-Frankivsk Region). It is an inselberg, rising above the plateau between the valleys of the Hnyla Lypa and Studenyi Potik rivers. Its bedrock is formed of calcareous marls to clayey limestones of the Cretaceous age, overlain by Neogene gypsum (Gerasimov et al., 2004). The site is protected since 1936 (Haydukevych, 2016), in the present form since 1975 as a Botanical Nature Monument of national importance with the area of 13 ha (Zamoroka et al., 2018).

The hill is a part of the physiographic region of Rohatyn Opillia, which belongs to a broader region of the Volyno-Podolian Upland. The surrounding landscape is hilly, with elevations between 250 and $430 \mathrm{~m}$ a.s.l. Mesophilous forests dominated by Quercus robur, Carpinus betulus, and Fagus sylvatica prevail in nearnatural vegetation. Species-rich steppe grasslands and calcareous fens are scattered throughout the region, containing many habitat specialists and rare species, indicating a long history of open landscape.

\section{Methods}

Taxonomic concepts and nomenclature of vascular plant taxa mainly follow Euro +Med PlantBase (2006onward). Syntaxonomic nomenclature follows Mucina et al. (2016) down to the alliance level and Willner et al. (2019) at the association level.

\section{Results}

Recent occurrence of Ophrys insectifera at Chortova Hora was recorded on 3 June 2019. A single individual was noticed in the steppe meadow situated in the lower part of a steep northern slope. Documentary photos of the plant were taken (Fig. 1) and geographical coordinates were recorded $\left(49^{\circ} 24^{\prime} 11.0^{\prime \prime} \mathrm{N}, 24^{\circ} 39^{\prime} 53.8^{\prime \prime} \mathrm{E}\right)$. The site has not been thoroughly searched due to limited time, so the occurrence of more individuals cannot be ruled out.

The accompanying species included Brachypodium pinnatum, Briza media, Cirsium pannonicum, Filipendula vulgaris, Galium boreale, Gymnadenia conopsea, Helictochloa hookeri subsp. schelliana, Hypochaeris maculata, Lembotropis nigricans (Cytisus nigricans), Peucedanum cervaria (Cervaria rivini), Polygala comosa, Ranunculus breyninus, and Thesium linophyllon. The herb layer cover was relatively low as compared to the surrounding stands (about 65\%). There was some litter accumulated on the ground as the vegetation was not burned that year.

\section{Discussion}

\section{New find}

The find reported here confirms the occurrence of Ophrys insectifera at Chortova Hora and whole Ukraine after 99 years. I assume the species was overlooked and was continuously present at the site, despite frequent visits by botanists. The small population size and perhaps also irregularity in flowering (Dorland, Willems, 2002) may have contributed to the neglect. Moreover, suitability of available habitats at Chortova Hora for the species is questionable. While steppe grasslands on the sun-exposed slopes may be too dry, grasslands on a shady slope may be too tall and closed, leaving little space for this lowgrowing species. Stands of the kind where Ophrys was found, with lower cover of herbs and grasses and high abundance of competitively inferior mesophilous species (e.g. Gymnadenia conopsea and Ranunculus breyninus), are less abundant on the shady slope and should preferably be explored when searching for the species.

\section{Conservation management}

The vegetation on the northern slope of Chortova Hora may be classified to a broadly circumscribed association Brachypodio pinnati-Molinietum arundinaceae from the alliance Cirsio-Brachypodion pinnati (class Festuco- 

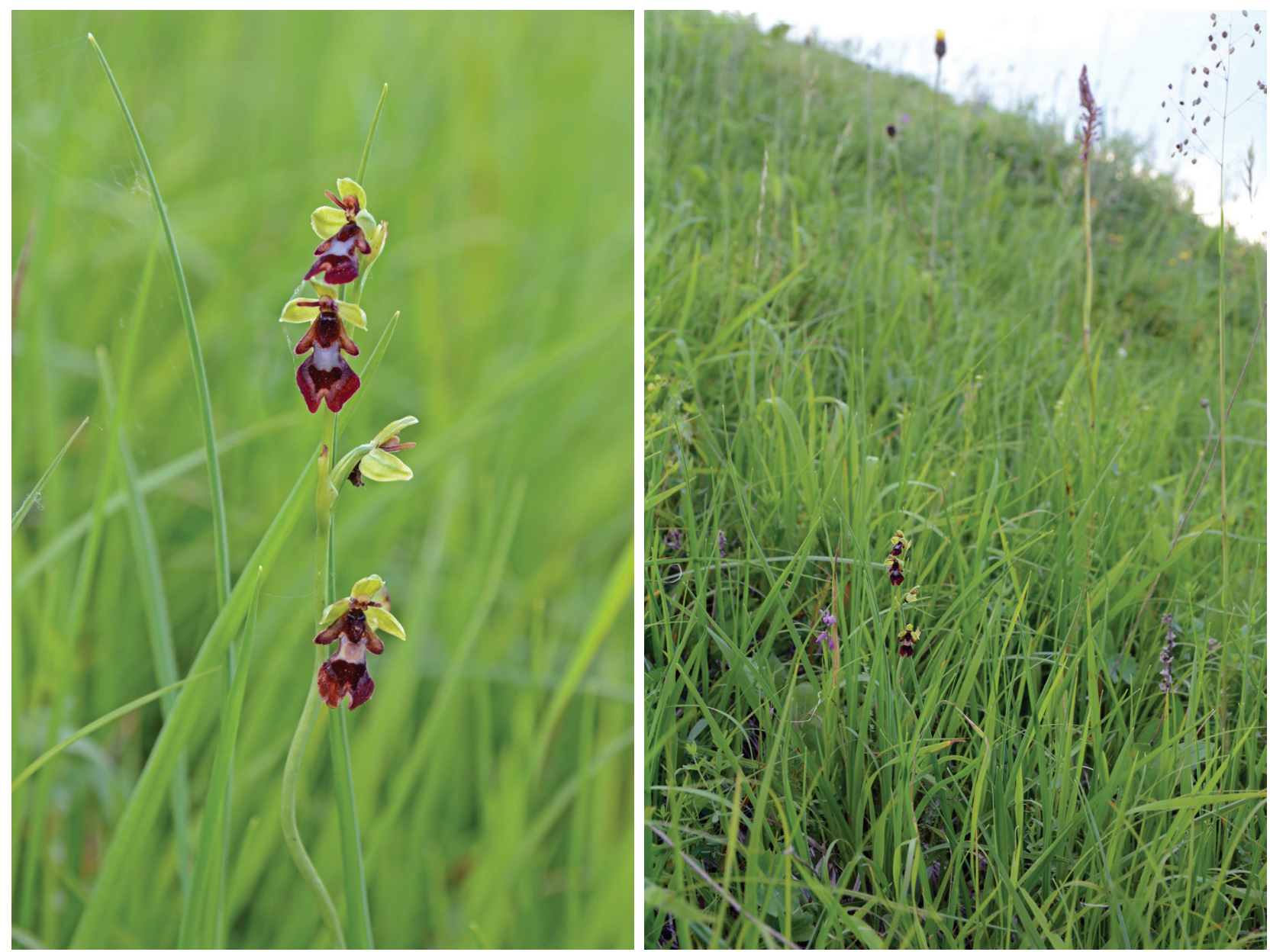

Fig. 1. Ophrys insectifera in steppe meadow at Chortova Hora near Rohatyn

Brometea) (Roleček et al., 2019; Willner et al., 2019). This type of dry-mesic steppe meadows is very species rich, but at the same highly productive, and thus preservation of its plant diversity requires regular biomass removal, which was historically done mainly through mowing (Roleček et al., 2014). Also, the grasslands at Chortova Hora used to be utilized for haymaking, probably combined with grazing (Haydukevych, 2016; Zamoroka et al., 2018). Recently, however, none of these management forms was applied and biomass removal was done through off-season grassland burning. During my last visits in 2019 and 2021, I have not observed any traces of burning, while litter accumulation was apparent.

To facilitate survival of $O$. insectifera and other poor competitors, it is necessary to continue some form of conservation management. If mowing and low-intensity grazing are not available, continuation of the previously practiced early spring burning may be an ecologically convenient and economically affordable option. According to recent studies, burning may prevent or slow down successional changes of forest-steppe habitats following their abandonment (Dmytrash-Vatseba, Shumska, 2020; Ónodi et al., 2021). This is in agreement with our observations from a number of steppe grasslands in Western Ukraine and Romania (Roleček et al., 2019, 2021). Although detrimental effects of burning have been reported too (Ruprecht et al., 2013; Polchaninova et al., 2019), I assume that positive effects prevail, as litter accumulation and woody species encroachment may be very harmful for the diversity of steppe species (Ruprecht et al., 2010; Kelemen et al., 2013; Boch et al., 2019). Despite recent efforts to eradicate spring burning of the grasslands in Ukraine (Burkovskyy et al., 2013; https://necu.org.ua/zupynymo-vogon-razom) controlled and properly timed burning of abandoned steppes may be viewed as an effective habitat management tool. 


\section{Acknowledgements}

I dedicate this paper to the memory of Nadiya V. Shumska, a recently deceased expert in the Western Ukrainian steppes, who introduced me to the flora of Chortova Hora. I would like to thank Barbora Rolečková, Prokop Roleček and Alena Rolečková for the pleasant company during the field trip in 2019, Beata Paszko for providing information from the Herbarium of the W. Szafer Institute of Botany in Krakow, and Anna A. Kuzemko for useful comments on the manuscript.

This paper was prepared with the support of the Czech Science Foundation (Project 20-09895S) and the Czech Academy of Sciences (long-term developmental project RVO 67985939).

\section{References}

Bardunov L.V., Novikov V.S. 2008. Krasnaya kniga Rossiyskoy federatsii (rasteniya $i$ griby). Moscow: Ministerstvo prirodnykh resursov i ekologii RF i Rosprirodnadzor, 856 pp. [Бардунов Л.В., Новиков, В.С. 2008. Красная книга Российской федерации (растения и грибы). Москва: Министерство природных ресурсов и экологии РФ и Росприроднадзор, 856 с.]

Boch S., Bedolla A., Ecker K.T., Ginzler C., Graf U., Küchler H., Küchler M., Nobis M.P., Holderegger R., Bergamini A. 2019. Threatened and specialist species suffer from increased wood cover and productivity in Swiss steppes. Flora, 258: 151444 (9 pp.). https://doi.org/10.1016/j. flora.2019.151444

Bornand C., Gygax A., Juillerat P., Jutzi M., Möhl A., Rometsch S., Sager L., Santiago H., Eggenberg S. 2016. Rote Liste Gefässpflanzen. Gefährdete Arten der Schweiz. Bern: Bundesamt für Umwelt, 178 pp.

Burkovskyy O.P., Vasylyuk O.V., Yena A.V., Kuzemko A.A., Movchan Y.I., Moysiyenko I.I., Sirenko I.P. 2013. Ostanni stepy Ukrainy: buty chy ne buty. Kyiv: Geoprynt, 38 pp. [Бурковський О.П., Василюк О.В., Єна А.В., Куземко А.А., Мовчан Я.І., Мойсієнко I.І., Сіренко І.П. 2013. Останні степи України: бути чи не бути. Київ: Геопринт, 38 с.]

Chorney I.I., Budzhak V.V., Tokaryuk A.I. 2010. Storinkamy Chervonoyi knyhy Ukrayiny (roslynnyy svit). Chernivetska oblast. Chernivtsi: DrukArt, 448 pp. [Чорней I.I., Буджак В.В., Токарюк А.I. 2010. Сторінками Червоної книги України (рослинний світ). Чернівецька область. Чернівці: ДрукАрт, 448 с.]

Dorland E., Willems J.H. 2002. Light climate and plant performance of Ophrys insectifera; a four-year field experiment in The Netherlands 1998-2001. In: Kindlmann P., Williams J., Whigham D.F. (eds.). Trends and fluctuations and underlying mechanisms in terrestrial orchid populations.. Leiden: Backhyus Publishers, pp. 225-238.
Dmytrash-Vatseba I.I. 2018. Rare species of vascular plants in Southern Opillya: population state, threats and conservation perspectives: Cand. Sci. Diss. (thesis for Ph.D. in Biology). Kyiv, M.G. Kholodny Institute of Botany NAS of Ukraine, 307 pp. (manuscript). [Дмитраш-Вацеба I.I. 2018. Раритетні види рослин Південного Опілля: стан популяцій, загрози і перспективи збереження: дис. ... канд. біол. наук (доктора філософії): спец. 03.00.05 "Ботаніка". Київ, Інститут ботаніки ім. М.Г. Холодного, 370 с. (рукопис)]

Dmytrash-Vatseba I.I., Shumska N.V. 2020. Dynamics of plant cover of meadow steppes after the cessation of traditional management in Opillia. Biosystems Diversity, 28: 224-229. https://doi.org/10.15421/012029

Euro + Med PlantBase - the information resource for EuroMediterranean plant diversity. 2006-onward. Available at: http://ww2.bgbm.org/EuroPlusMed (Accessed 25 May 2021).

Galeyeva A.Kh. 2006. Vestnik Orenburgskogo gosudarstvennogo universiteta, 2006/4: 19-22. [Галеева А.Х. 2006. Редкие виды семейства орхидных в Красной книге Республики Башкортостан и критерии их отбора. Вестник Оренбургского государственного университета, 2006/4: 19-22.]

Gerasimov L.S., Chaliy S.V., Gerasimova I.I. 2004. Geological map and map of mineral resources of pre-Quaternary units. Volyno-Podilska Series. M-35-XIX (Lviv). Kyiv: Ukrainian State Geological Research Institute, 16 pp.

Grulich V., Chobot K. (eds.). 2017. Červený seznam ohrožených druhů České republiky. Cévnaté rostliny. Príroda, 35: 1-178.

Haydukevych O. 2016. Metropolitan Andrei Sheptytskyi environmental representative of Halychyna. Skhid, 141(1): 35-39. [Гайдукевич О. 2016. Митрополит Андрей Шептицький - природоохороний діяч Галичини. Сxid, 141(1): 35-39.]

Hyvärinen E., Juslén A., Kemppainen E., Uddström A., Liukko U.-M. (eds.). 2019. The 2019 Red List of Finnish species. Helsinki: Ympäristöministeriö \& Suomen ympäristökeskus, 704 pp.

Kagalo A.A. 2009. Ophrys insectifera. In: Red Data Book of Ukraine. Plant kingdom. Ed. Ya.P. Didukh. Kyiv: Globalconsulting, p. 200. [Кагало О.О. 2009. Ophrys insectifera. В кн.: Червона книга Украӥни. Рослинний cвim. Ред. Я.П. Дідух. Київ: Глобалконсалтинг, с. 200].

Kaźmierczakowa R., Bloch-Orłowska J., Celka Z., Cwener A., Dajdok Z., Michalska-Hejduk D., Pawlikowski P., Szczęśniak E., Ziarnek K. 2016. Polska czerwona lista paprotników $i$ roślin kwiatowych. Kraków: Instytut Ochrony Przyrody Polskiej Akademii Nauk, 44 pp.

Kelemen A., Török P., Valkó O., Miglécz T., Tóthmérész B. 2013. Mechanisms shaping plant biomass and species richness: plant strategies and litter effect in alkali and loess grasslands. Journal of Vegetation Science, 24(6): 11951203. https://doi.org/10.1111/jvs.12027

Metzing D., Hofbauer N., Ludwig G., Matzke-Hajek G. (eds.). 2018. Rote Liste gefährdeter Tiere, Pflanzen und Pilze Deutschlands. Band 7: Pflanzen. Bonn-Bad Godesberg: Bundesamt für Naturschutz, 784 pp. 
Meusel H., Jäger E.J., Weinert E. 1965-1992. Vergleichende Chorologie der zentraleuropäischen Flora I-III. Jena: Gustav Fischer Verlag, 688 pp.

Mucina L., Bültmann H., Dierssen K., Theurillat J.-P., Raus T., Čarni A., Šumberová K., Willner W., Dengler J., Gavilán García R., Chytrý M., Hájek M., Di Pietro R., Iakushenko D., Pallas J., Daniëls F.J.A., Bergmeier E., Santos Guerra A., Ermakov N., Valachovič M., Schaminée J.H.J., Lysenko T., Didukh Ya.P., Pignatti S., Rodwell J.S., Capelo J., Weber H.E., Solomeshch A., Dimopoulos P., Aguiar C., Hennekens S.M., Tichý L. 2016. Vegetation of Europe: hierarchical floristic classification system of vascular plant, bryophyte, lichen, and algal communities. Applied Vegetation Science, 19 (Suppl. 1): 3-24. https://doi.org/10.1111/avsc.12257

Oltean M., Negrean G., Popescu A., Roman N., Dihoru G., Sanda V., Mihăilescu S. 1994. Studii, sinteze, documentaţii de ecologie. Lista roşie a plantelor superioare din România. București: Academia Română, Institutul de Biologie, $52 \mathrm{pp}$.

Ónodi G., Kertész M., Lengyel A., Pándi I., Somay L., Szitár K., Kröel-Dulay G.2021. The effects of woody plant encroachment and wildfire on plant species richness and composition: Temporal changes in a forest-steppe mosaic. Applied Vegetation Science, 24(1): e12546. https://doi. org/10.1111/avsc. 12546

Petrova A., Vladimirov V. 2009. Red List of Bulgarian vascular plants. Phytologia Balcanica, 15(1): 63-94.

Polchaninova N., Savchenko G., Ronkin V., Drogvalenko A., Putchkov A. 2019. Summer fire in steppe habitats: longterm effects on vegetation and autumnal assemblages of cursorial arthropods. Hacquetia, 18(2): 213-231. https:// doi.org/10.2478/hacq-2019-0006

Shumska N.V., Dmytrash-Vatseba I.I. 2018. In: Biota luchnykh stepiv Burshtynskoho Opillya. Ed. A.M. Zamoroka. IvanoFrankivsk: Symfoniya forte, pp. 45-64. [Шумська Н.В., Дмитраш-Вацеба I.I. 2018. Флора лучних степів Бурштинського Опілля. В кн.: Біота лучних степів Бурштинського Опілля. Ред. А.М. Заморока. ІваноФранківськ: Симфонія форте, с. 45-64.]

Rankou H. 2011. Ophrys insectifera. The IUCN Red List of Threatened Species 2011: e.T175957A7153465. https://dx.doi.org/10.2305/IUCN.UK.2011-2.RLTS. T175957A7153465.en (Accessed 24 May 2021).

Roleček J., Čornej I.I., Tokarjuk A.I. 2014. Understanding the extreme species richness of semi-dry grasslands in eastcentral Europe: a comparative approach. Preslia, 86(1): $5-27$.

Roleček J., Hájek M., Dřevojan P., Prokešová H., Fajmon K., Těšitel J., Daněk P., Hájková P., Jongepierová I., Novák P., Poluyanov A.V., Shumska N.V., Chorney I.I. 2019. Gradients, species richness and biogeographical links of steppe grasslands in Western Podolia (Ukraine). Phytocoenologia, 49(4): 349-367. https://doi.org/10.1127/ phyto/2019/0255
Roleček J., Dřevojan P., Iakushenko D., Hájek M. 2021. Tall herb-rich steppe in the peri-Carpathian region of Ukraine and Romania. Phytocoenologia, in press. https://doi. org/10.1127/phyto/2021/0388

Roze D., Belogrudova I., Jakobsone G., Megre D., Klavina D. 2011. Some aspects of the ecology of Ophrys insectifera. International Journal of Arts \& Sciences, 4(19): 107-120.

Ruprecht E., Enyedi M.Z., Eckstein R.L., Donath T.W. 2010. Restorative removal of plant litter and vegetation 40 years after abandonment enhances re-emergence of steppe grassland vegetation. Biological Conservation, 143(2): 449-456.

Ruprecht E., Fenesi A., Fodor E.I., Kuhn T. 2013. Prescribed burning as an alternative management in grasslands of temperate Europe: the impact on seeds. Basic and Applied Ecology, 14: 642-650.

Stroh P.A. 2015. Ophrys insectifera. In: Fly Orchid. Species Account. BSBI. Available at: https://bsbi.org/wp-content/ uploads/dlm uploads/Ophrys insectifera species account.pdf

Willner W., Roleček J., Korolyuk A., Dengler J., Chytrý M., Janišová M., Lengyel A., Aćić S., Becker T., Ćuk M., Demina O., Jandt U., Kącki Z., Kuzemko A., Kropf M., Lebedeva M., Semenishchenkov Y., Šilc U., Stančić Z., Staudinger M., Vassilev K., Yamalov S. 2019. Formalized classification of semi-dry grasslands in central and eastern Europe. Preslia, 91: 25-49. https://doi.org/10.23855/ preslia.2019.025

Wind P. 2019. Karplanter. In: Moeslund J.E. (ed.). Den danske Rødliste 2019. Aarhus: Aarhus Universitet, DCE Nationalt Center for Miljø og Energi. Available at: $\underline{\text { https:// }}$ bios.au.dk/forskningraadgivning/temasider/redlistframe (Accessed 31 May 2019).

Wolff T. 1951. Ecological investigations on the Fly Ophrys, Ophrys insectifera L. in Allindelille Fredskov, Denmark. Oikos, 3: 71-97.

Zamoroka A.M., Shumska N.V., Dmytrash-Vatseba I.I. 2018. In: Biota luchnykh stepiv Burshtynskoho Opillya. Ed. A.M. Zamoroka. Ivano-Frankivsk: Symfoniya forte, pp. 16-30. [Заморока А.М., Шумська Н.В., ДмитрашВацеба I.I. 2018. Інвентаризація лучних степів Бурштинського Опілля. В кн.: Біота лучних степів Бурштинського Опілля. Ред. А.М. Заморока. ІваноФранківськ: Симфонія форте, с. 16-30.]

Recommended for publication by I. Korotchenko 
Ролечек Я. 2021. Недавня знахідка Ophrys insectifera (Orchidaceae) в Україні - чи переживе цей вид ще одне століття? Украӥнський ботанічний журнал, 78(4): 297-302 [In English].

Інститут ботаніки, Академія Наук Чеської Республіки, вул. Лідіцька 25/27, Брно 657 20, Чеська Республіка; Університет Масарика, вул. Котляржська 37, Брно 611 37, Чеська Республіка: Я. Ролечек

Реферат. Повідомлення присвячене першій з 1920 року знахідці Ophrys insectifera в Україні. Одна особина виду була знайдена на місці його попередньої реєстрації, а саме на Чортовій горі поблизу Рогатина (ІваноФранківська обл.). Оселище виду - лучно-степова ділянка у нижній частині крутого північного схилу. Рослинність локалітету може бути віднесена до асоціації Brachypodio pinnati-Molinietum arundinaceae 3 союзу Cirsio-Brachypodion pinnati (клас Festuco-Brometea). У повідомленні обговорюються можливі причини тривалої відсутності знахідок $O$. insectifera на цій ділянці, умови ії існування та належне природоохоронне управління. Для забезпечення подальшого існування цього виду, який має слабку конкурентну здатність, а також інших рідкісних видів, необхідно запобігати накопиченню опаду й підстилки та природній сукцесії - зміни трав'яної рослинності на деревно-чагарникову. Для досягнення цього може бути запропоноване скошування травостою, низькоінтенсивний регульований випас худоби, контрольоване ранньовесняне випалювання підстилки, або ж поєднання усіх цих заходів.

Ключові слова: загрози, зникаючі види, контрольоване випалювання, Опілля, поширення рослин, природоохоронне управління, сукцесія 